\title{
The Creative Thinking Skill of Biological Learning Students at Candi Baru High School
}

\author{
Adieba Warda Hayya ${ }^{1)}$ \\ ${ }^{1)}$ Tadris Biologi Institut Agama Islam Kudus \\ adiebawarda@iainkudus.ac.id
}

\begin{abstract}
The aim of this study was to describe the skill of students to think creatively about Biology at Candi Baru high school (HS). The study used a qualitative approach using a case study method. The population in this study was students of Candi Baru HS from the academic year 2016/2017. This research uses randomized cluster sampling. Samples were XI Mathematic and Science (MIA) 6, 7, and 8 classes. Data collected by observation and document collection, using a human instrument, an observation sheet and a categorization sheet. Data research included the quality of the student's; answers, works, and responses during the learning process. Data analysis was carried out descriptively by comparing the results of the research with information derived from literature or theory. The results showed that students' level of creative thinking skill is still low and the assessment provided by the teacher has not reached the students' creative thinking skill.
\end{abstract}

\section{Keywords : creative, creative thinking, creative thinking skill, creative thinking of biological learning, higher order thinking}

\section{INTRODUCTION}

The ability to think creatively is the principal aim of education. Creative thinking is explicitly mentioned as a valuable educational goal in curricula around the world (Hadzigeorgiou, Fokialis, \& Kabouropoulou, 2012) Some of the countries that focus on creative thinking are g Sweden, Australia, United Kingdom, Malaysia, and Hong Kong. These countries highlight the importance of equipping students with creative thinking skills. (Hui, 2003; Papaleontiou- Louca, Varnava-Marouchou, Mihai, \& Konis, 2014; Piawa, 2010).

Today's world is the product of the creative thinking of several individuals. Communication, transportation, medicine and other technology tools are examples of creative thinking products. This encourages the enormous demand for creative workforce capacity is very large, so they expect schools to teach and assess student creativity (Beghetto, 2010)

Biology is one discipline that can contribute to the attainment of that goal. Through learning Biology, the nation's progress towards science and technology can train scientists. Also 
through Biology, we can teach many of skills that underlie creativity, such as asking questions, giving challenges, making connections, and solving problems.

Creative thinking skills are the ability of individuals to use their minds to produce original, novel ideas. The ability to think creatively is shown by the ability of students to produce multiple ideas (fluency), the ability to provide different answers from previous answers (flexibility) and the ability to provide unique, fresh and unexpected ideas when faced with a question (novelty).

The study was conducted at one of Semarang's favorite and famous high schools, and in this study we disguised the name of the school as Candi Baru HS. There is no valid information at the school about the ability to think creatively. Based on the results of teacher interviews, it is understood that students' creative thinking skills are high, but based on the results of field observations, it indicates that students' creative thinking skills are still weak. The poor ability of students to think creatively is measured by the few ideas that students express during learning, other than that there are no new ideas or ideas communicated by students while learning takes place. Students prefer not to answer questions from the teacher or simply answer them with simple responses.

The explanation shows that knowledge about students' creative thinking skills needs to be understood so that both teachers and students can build learning that promotes creative thinking skills. Everybody has imaginative abilities that can be improved by learning. This research explains students' creative thinking skills in studying biology at Candi Baru HS. In order to explore this emphasis, this study will use qualitative approaches to make it easier for researchers to deal with reality in order to obtain in-depth data. Statistics were derived from observations on the quality of student answers to questions, the quality of student work in the execution of assignments, and the quality of student responses during the course of study.

The findings of this research are insights that help discuss knowledge about students' creative thinking skills so that help the teacher use them as a tool for the learning process in the classroom. The results of the description and analysis of students' creative thinking skills in learning biology are also useful for improving the teaching practices of the teacher. In addition, the findings are useful to the government as a guide to the implementation of learning preparation policies that can promote the innovative thinking of students. Based on the definition, the purpose of the research is to find a representation of students' creative thinking skills in learning biology at Candi Baru HS.

\section{RESEARCH METHOD}

The study lasted four months using a case study approach. The population of Candi Baru HS students in the school year 2016/2017 was nine classes. Sampling using cluster sampling methods, namely XI MIA 6, XI MIA 7 and XI MIA 8 groups. Data collection methods using observation and record processing aided by instruments in the form of human instruments, observation sheets and categorization sheets. Data were given in the quality of the student's answers to the questions, the quality of the student's work in carrying out the assignment, and the quality of the student's response during learning. 
The data analysis methodology used in this research is a qualitative method data analysis technique (Creswell, 2014). Data analysis shall include the processing of data, the reading of all data, the coding of data, the coding of each category, the presentation of a description/theme in the form of a narration and the making of interpretation/interpretation data.

\section{RESULT AND DISCUSSION}

\section{The Quality of Student Answers to Questions}

During the study, we collected answers from the questions given by the teacher. The questions given were test questions, block 1 question, and block 2 tests, and the questions in the worksheet. They gave the questions to all students of class XI MIA 6, XI MIA 7, and XI MIA 8, while they only gave the questions contained in the worksheet to students of class XI MIA 6 and XI MIA 7.

The test questions put to the teacher are a matter of a closed type description. Another question is the block test, which is a combined evaluation of the two materials which have been studied. The test block consisted of 40 multiple-choice questions and 5 closed questions. While the test consists of 20 multiple-choice questions and 5 item description items. Table 1 presents the quality of students' answers to questions. From table 1 it is known that students have a variety of ways to answer, but only few student answer original things.

It is known from the explanation above that the test questions test blocks 1 and 2 are multiple-choice questions and closed descriptions, so that the answers are only in the form of student memories of the material that there are no student ideas in answering questions. Besides, the answers to the questions in the workbook indicate, the students' ideas are because the questions are in the form of open-ended questions.

\section{The Quality of Student Work in the Execution of Assignments}

The tasks got during the study are the tasks of reporting on the practice: blood smears, blood pressure, and compound content in food ingredients, and creating cards, drawing the structure of the ruminant digestive organs, and downloading Obesity and Food Ingredient Test games.

The format of the practicum report assigned to the teacher is the title, objectives, tools and materials, work methods, observations and conclusions. Based on the analysis carried out, it is difficult to find the creative thinking skills of the students, because the format of the practicum 
report did not provide the space for students to convey their ideas. Researchers are therefore unable to further analyze student responses. The format of the report submitted to the students is in the form of a closed description.

Making a card is an assignment to students on the material structure and function of tissue cells in plants and animals. Table 2 presents qualitative data on the tasks of the card. Students were assigned to draw tissue from the teacher on $8 \times 10 \mathrm{~cm}$ paper. From the assignments collected by the students, it can be analyzed that the students have different ways to solve the problems of the teacher.

Besides making cards, another task given by the teacher was to draw the structure of the digestive organs of ruminant animals in groups. In class XI MIA 6, students did well in their respective groups. Students show that they have various solutions in doing the assignments given by the teacher, this is determined from the work of students. Students have various ways to present pictures of animal digestion through an image. Students can show the digestive system of ruminant animals by distinguishing each organ with a distinct color, students also give the names of the digestive organs of animals drawn. However, only five groups did original things, the group gave a sign for the order of food coming into going out.

We also see this in class XI MIA 7, students have a variety of ways to present the digestion of ruminant animals through a picture. Students can show the digestive system of ruminant animals by distinguishing each organ with a distinct color, students also give the names of the digestive organs of animals drawn. However, only two groups gave signals for the order in which food out, and 1 group gave a detailed description of each organ.

Similar to class XI MIA 8, students also have a variety of ways to present the digestion of ruminant animals through a picture. Students can show the digestive system of ruminant animals by distinguishing each organ with a distinct color, students also give the names of the digestive organs of animals drawn. However, only one group did an original thing than the others, the group gave a sign for the order of food coming in and going out, and there was one group that gave detailed explanations of each organ.

From the explanation above, it is known that some groups work with things different from other groups and provide improvisation in doing the task. This shows that students' creative thinking ability is still low, but the number of groups that do this is still small, even in class XI MIA 7 and XI MIA 8 only 1 group does original things. 
Another task is downloading obesity and food games can not be analyzed because there is no authentic evidence of students doing, and researchers can not observe directly when students play games because they are not done during school hours.

Table 1. The Quality of Students' Answers to Questions

\section{MIA 6 Class}

\begin{tabular}{|c|c|c|c|}
\hline Questions & Answer Summary & Number & Example \\
\hline \multirow[t]{3}{*}{$\begin{array}{l}\text { "The disease } \\
\text { generally begins with } \\
\text { what is eaten and } \\
\text { how it is eaten." } \\
\text { What do you think of } \\
\text { this statement? }\end{array}$} & $\begin{array}{l}\text { Justifying the phrase, } \\
\text { "The disease generally } \\
\text { begins with what is eaten } \\
\text { and how it is eaten," } \\
\text { without giving his } \\
\text { opinion. }\end{array}$ & 18 & 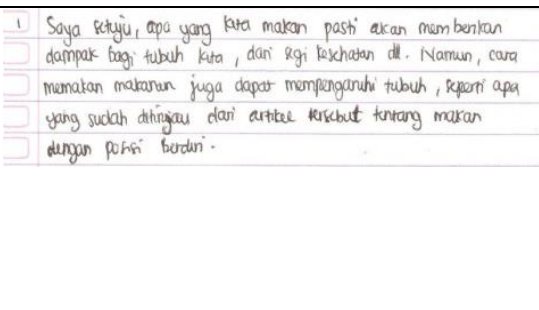 \\
\hline & $\begin{array}{l}\text { Give answers by giving } \\
\text { examples to reinforce his } \\
\text { opinion. }\end{array}$ & 5 & 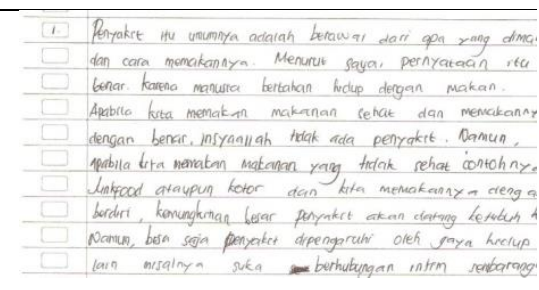 \\
\hline & $\begin{array}{l}\text { Explain the answers to the } \\
\text { questions presented with } \\
\text { the scientific explanation }\end{array}$ & 5 & 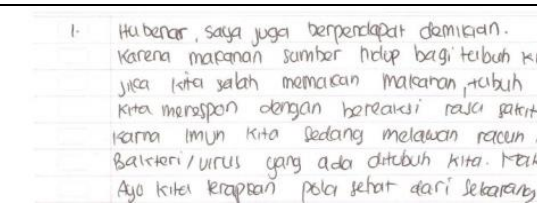 \\
\hline \multirow{3}{*}{$\begin{array}{l}\text { How is the essence } \\
\text { of our body feeding } \\
\text { according to what } \\
\text { you know? }\end{array}$} & $\begin{array}{l}\text { answer shortly that eating } \\
\text { is a source of energy and } \\
\text { so on }\end{array}$ & 22 & 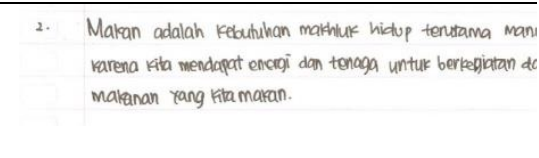 \\
\hline & $\begin{array}{l}\text { explain how food is useful } \\
\text { for the body }\end{array}$ & 3 & 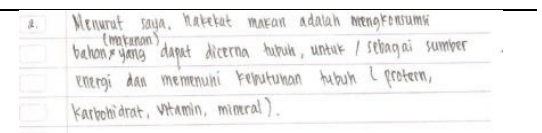 \\
\hline & $\begin{array}{l}\text { have almost the same } \\
\text { answer that eating is } \\
\text { nourishing the body }\end{array}$ & 3 & 2. Hokekat makan oddah memberi nutrisi atou osupan ff \\
\hline $\begin{array}{l}\text { What behaviors are } \\
\text { you going to have in } \\
\text { relation to the }\end{array}$ & $\begin{array}{l}\text { states agree that eating } \\
\text { while standing is not good }\end{array}$ & 15 & $\begin{array}{l}\text { 3. Tidak setufu. dengan gaya hidup makan sambil berdiri, } \\
\text { selain dikarenakan bahaya penyakt, juga bagig trob } \\
\text { ith hal yang tidak elok, tidak sopan. }\end{array}$ \\
\hline
\end{tabular}




\begin{tabular}{|c|c|c|c|c|}
\hline $\begin{array}{l}\text { lifestyle of eating } \\
\text { while standing? } \\
\text { Please complete with } \\
\text { your point! }\end{array}$ & $\begin{array}{l}\text { Express authorisation is } \\
\text { followed by scientific } \\
\text { explanations }\end{array}$ & 1 & 3. & 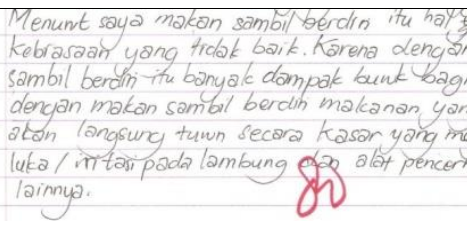 \\
\hline & $\begin{array}{l}\text { States no problem eating } \\
\text { while standing as long as } \\
\text { it is not often }\end{array}$ & 13 & 3 & 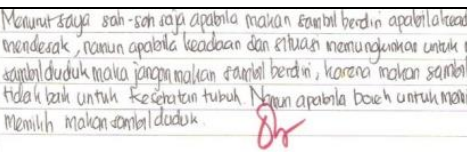 \\
\hline & $\begin{array}{l}\text { States agree that eating } \\
\text { while standing is not good } \\
\text { and will remind friends } \\
\text { and others who eat while } \\
\text { eating while standing up }\end{array}$ & 2 & 3 & 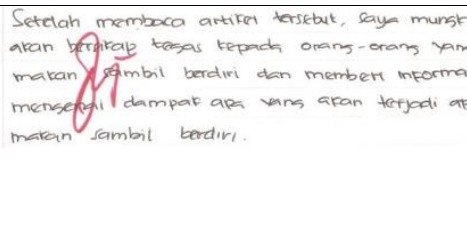 \\
\hline
\end{tabular}

\begin{tabular}{|c|c|c|c|}
\hline \multicolumn{4}{|c|}{ XI MIA 7} \\
\hline Questions & Answers Summary & Number & Example \\
\hline \multirow[t]{4}{*}{$\begin{array}{l}\text { "The disease generally } \\
\text { begins with what is } \\
\text { eaten and how it is } \\
\text { eaten." What do you } \\
\text { think of this statement? }\end{array}$} & $\begin{array}{l}\text { Justifying the phrase, } \\
\text { "The disease generally } \\
\text { begins with what is eaten } \\
\text { and how it is eaten," } \\
\text { without giving his } \\
\text { opinion. }\end{array}$ & 17 & 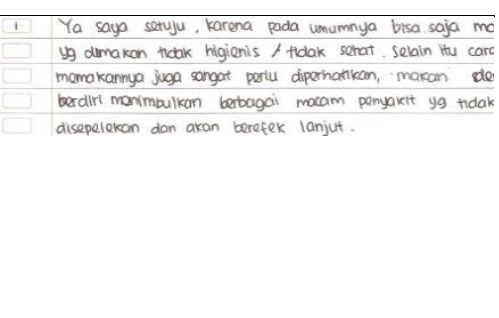 \\
\hline & $\begin{array}{l}\text { States agree, and } \\
\text { scientifically express their } \\
\text { reasons, and they are able } \\
\text { to combine their } \\
\text { knowledge in order to be } \\
\text { able to express their } \\
\text { opinions. }\end{array}$ & 7 & 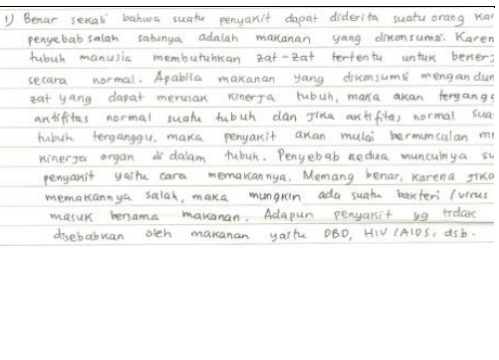 \\
\hline & $\begin{array}{l}\text { answer by writing } \\
\text { examples of foods that } \\
\text { can cause disease }\end{array}$ & 2 & 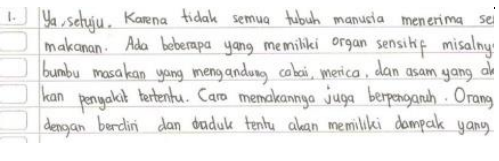 \\
\hline & $\begin{array}{l}\text { Answer that illness may } \\
\text { come from thought }\end{array}$ & 1 & 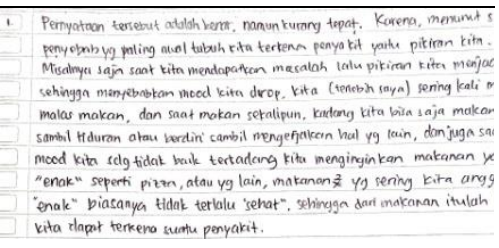 \\
\hline
\end{tabular}


How is the essence of our body feeding according to what you know? answer shortly that eating

17

is a source of energy and

so on

explain how food is useful 15

for the body
Hokekat makan bagi tubuh ktta untuk memperoleh er 2at - 2at yang dipornukan oleh tubuh. Agar bisa , keglatan - kogiatan sehari - hari dongan energi ug dari makan.

What behaviors are
$\begin{aligned} & \text { states agree that eating } \\ & \text { you going to have in } \\ & \text { relation to the lifestyle } \\ & \text { of eating while standing is not good }\end{aligned}$

Explain that eating while
standing is a lifestyle that
has become a habit, so the
attitude that must be taken
is to follow these
developments.

\section{Explanation :}

Question : Questions which students got

Answer Summary : Summary of Student Content Answers

Number : Number of students working on it

Example : Example of student answers

Table 2. Quality of Student Work Outcomes in the Performance of the Card Making Task

\begin{tabular}{c|c|c|c|c|c|c}
\hline Student Work & \multicolumn{3}{|c|}{ Total } & \multicolumn{4}{c}{ Examples of Student Work Results } \\
\hline & A & B & C & A & B & C \\
\hline
\end{tabular}




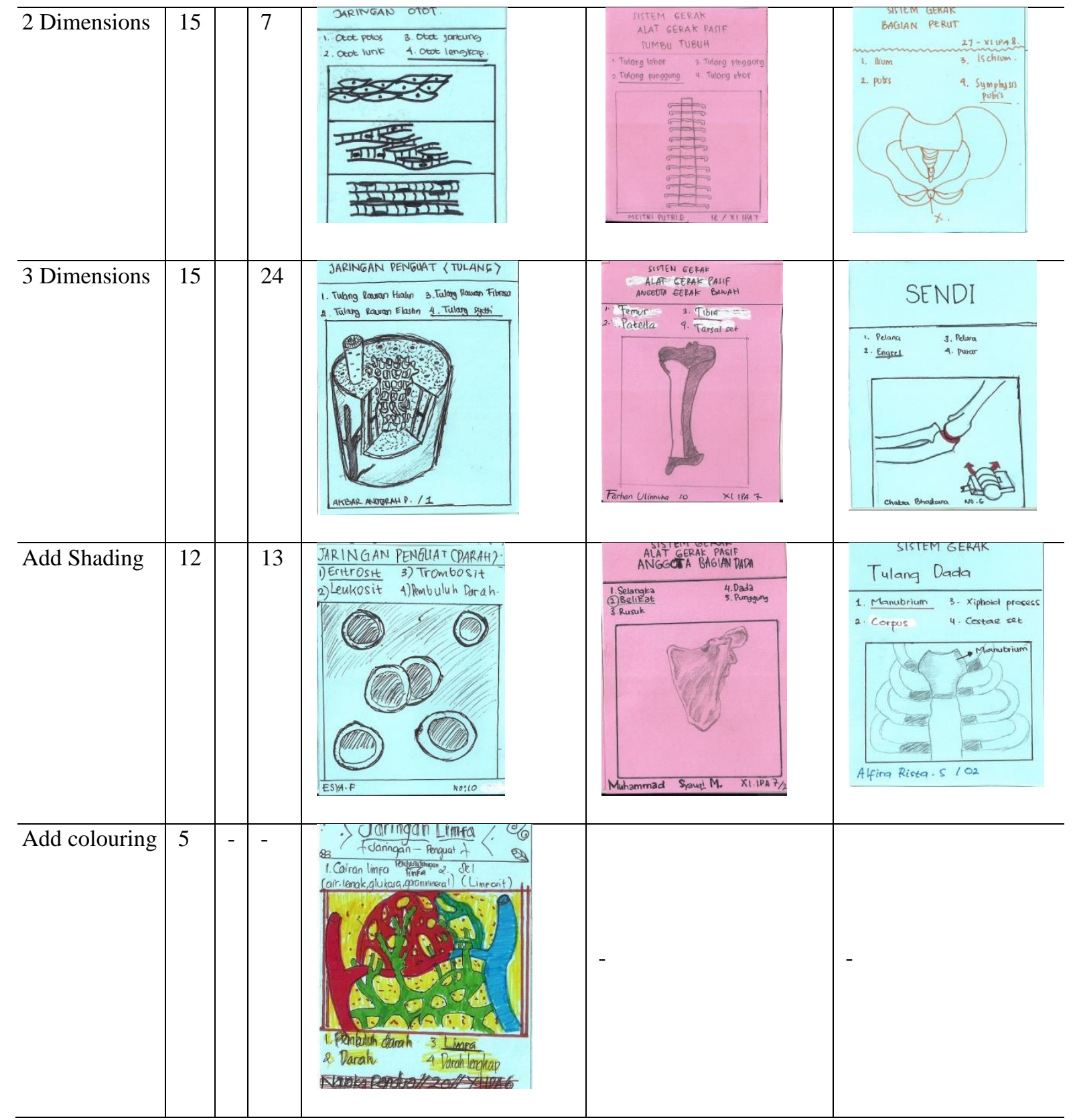

\section{Explanation :}

Student Work

Total

A

B

C
: Summary of Student Work Outcomes

: Number of students working on it

: XI MIA 6 Class

: XI MIA 7 Class

: XI MIA 8 Class 


\section{The Quality of Student Responses during Learning}

During the study, the material presented by the teacher included the structure and function of cells that make up tissues in plants and animals, the motion system, the circulation system and the digestive system. The teacher communicates the material of the structure and function of cells that make up tissues in plants and animals, as well as the motion system, using the lecture method. While the material structure and role of the cells that make up the network in the circulatory system and the digestive system is communicated through discussion and practice. The teacher's questions during learning are just a reminder for students. Similarly, during practicum, teacher or student questions are often about the resources and materials needed, as well as the research that needs to be completed.

From all the answers to questions, work results and student responses during the learning collected, it is known that students 'creative thinking abilities can only be determined from students' assignments in the form of making cards, working on problems in worksheets, and drawing the structure of digestive organs of ruminants. Based on the analysis, it is known the questions given by the teacher to students to produce creative thinking skills is the questions with open-ended questions. Open-ended questions are items that ask only concerning the principal problem being discussed, without giving specific directions in answering it. Thus, students can develop their thoughts in answering questions, as long as they are relevant to the principal problem being asked. Divergent questions, also known as open questions, elicit a wide range of responses that often require substantive elaboration. Divergent questions do not have a single "best" response. Educators use divergent questions to stimulate dialog and explore a range of issues related to the topic.(Tofade, Elsner, \& Haines, 2013)

It is understood from the above that open-ended questions enable students to organize ideas and state their responses in accordance with their own words or phrases. The broad scope of the answers will assess the creative thinking skills of students Whereas closed-ended questions are questions that only have one correct answer (Agustianingsih \& Mahmudi, 2019). From this point of view, it can be seen that the closed-ended questions are questions that have been answered to certain issues or that there are other limitations. The students' answers, then, are the answers that the teacher needs or answers that are already limited. No novel ideas were then found on the answer sheet. 
For addition, there are multiple-choice questions that often do not allow students the ability to compose their thoughts, making it difficult to test students ' creative thinking skills. The question of the type of multiple-choice is a dilemma, the answer of which must be chosen from a number of possibilities and the answers given. Every multiple-choice question shall include the subject and the option of answer. Valenti (2003:320) also argues that multiple-choice questions only show memories and are difficult to quantify higher thought processes, apart from the fact that the probability of guessing answers is still big, and that communication between students when working on test questions is more accessible.(Valenti, Neri, \& Cucchiarelli, 2003)

Multiple-choice tests have several functional benefits, but multiple-choice tests can not assess other essential abilities in education and other information. Some skills are too complex to be measured effectively with multiple-choice question. Other skills and types of knowledge cannot be measured if the test-taker is shown a list that includes the correct answer (Livingston, 2009). Multiple-choice assessments are often used to determine the ability to remember, to learn, to relate, to grasp relationships, and to apply concepts. In fact, the multiple-choice test often allows students not accustomed to writing ideas using their own words, so the risk of guessing the answers is big and difficult to track. We know that one indicator of creative thinking ability is fluency, which means students can provide novel ideas.

On the basis of the above analysis, it can be concluded that multiple-choice questions are questions, the answers to which must be selected from a variety of choices and the answers given. As a result, multiple-choice questions can not assess students ' creative thinking skills due to the limitations of student responses. Whereas, based on findings and observation of learning biology in the classroom, students ' creative thinking skills are still weak. This is because there are no questions during learning that make students exchange thoughts or information, because all questions are about students' memories.

Teacher questions are a very important component of classroom communication and play a very important role in facilitating student learning. Teachers' questions during learning influence students' cognitive processes (Chin, 2007). There are two types of questions that teachers can use in the learning process, that is closed-ended and open-ended questions, but only open-ended questions that can stimulate the students to develop their higher-order thinking skills (Agustianingsih \& Mahmudi, 2019) Closed-ended questions can test comprehension, while open-ended questions have many potential answers that are not predetermined. 
Research on teacher questions has also shown that closed-ended questions are used by teachers rather than open-ended questions in the overall teaching practices in the classroom (Tofade et al., 2013)(. Valid assessment of higher order thinking skills requires that students be unfamiliar with the questions or tasks they are asked to answer or perform and that they have sufficient prior knowledge to enable them to use their higher order thinking skills in answering questions or performing tasks (King, Goodson, \& Faranak Rohani, 2011). So it is known that the teacher questions is important in learning, especially to encourage students' creative thinking skills because the questions with the open-ended questions help students to convey ideas and ideas they have.

A number of research ideas related to efforts to improve students' creative thinking skills can be summarized from the explanation above. Another such theory is that students are inspired to consciously express ideas when they get questions from the teacher. This can be done if students have insights on the subject or outside the subject. Some of the ways students can do that are reading books, journals, articles, or research findings related to the lesson. Students may master science and technology in books, papers, or articles with reading habits.

In addition, students will carry out research in the area of science. Work can be bundled in a realistic way. After the practicum has been completed, students should be allowed to communicate the results they have obtained from the practicum. Communicating the results is intended to encourage students to communicate or express new knowledge and validate it to the teacher. This makes students have a lot of ideas or thoughts about their ability to think creatively.

The next idea is that students are supposed to see the issue from various points of view when they get a question from the teacher. This is useful in such a way that the solutions offered by students are diverse or new, because novelty is one of the important aspects of the ability to think creatively. In addition, students are expected to have the ability to select alternate problemsolving solutions. It is achieved so that students are familiar with a variety of problems-solving and encourage students to solve problems with a variety of solutions. Moreover, although there is a learning potential that enhances the ability to think creatively, in reality the assessment is not yet supported. So it is expected that there is an assessment of students' creative thinking ability. 


\section{CONCLUSION}

Based on the research that has been done about students' creative thinking ability in Biology learning in Candi Baru HS, it can be concluded that students' creative thinking ability in Biology learning is still low. The assessments used by teachers have not been able to measure creative thinking ability, because assessments only measure students' cognitive abilities. In addition, students have not been facilitated to think creatively in biology learning.

\section{REFERENCES}

Agustianingsih, R., \& Mahmudi, A. (2019). How to design open-ended questions? : Literature review. Journal of Physics: Conference Series, 1320(1). https://doi.org/10.1088/17426596/1320/1/012003

Beghetto, R. A. (2010). Creativity in the Classroom. In Cambridge Handbook of Creativity (pp. 447-463). https://doi.org/10.1002/j.2162-6057.1968.tb00110.x

Chin, C. (2007). Teacher questioning in science classrooms: Approaches that stimulate productive thinking. Journal of Research in Science Teaching, 44(6), 815-843. https://doi.org/10.1002/tea.20171

Creswell, J. W. (2014). Research Design (Pendekatan kualitatif, Kuantitatif, dan Mixed). Yogyakarta: Pustaka Pelajar.

Hadzigeorgiou, Y., Fokialis, P., \& Kabouropoulou, M. (2012). Thinking about Creativity in Science Education. Creative Education, 03(05), 603-611. https://doi.org/10.4236/ce.2012.35089

Hui, M. F. (2003). Problems and Issues of the Teaching and Learning of Creativity in Hong Kong Schools. Apjted, 6(1), 103-124.

King, F., Goodson, L., \& Faranak Rohani, M. (2011). Higher Order Thinking Skills • Definition - Teaching Strategies - Assessment A publication of the Educational Services Program, now known as the Center for Advancement of Learning and Assessment. In Center for Advancement of Learning and Assessment. Retrieved from http://llt.msu.edu/issues/june2016/lee.pdfhttp://llt.msu.edu/issues/june2016/lee.pdf\%0Aw ww.cala.fsu.edu\%0Awww.ascd.org/memberbooks\%0Awww.21stcenturyskills.org\%0Ahtt $\mathrm{p}: / / \mathrm{www}$.

Livingston, B. S. a. (2009). Constructed-Response Test Questions: Why We Use Them; How We Score Them. $R \quad \& \quad D$ Connections, 11(11), 1-8. Retrieved from http://144.81.87.152/Media/Research/pdf/RD_Connections11.pdf

Papaleontiou- Louca, E., Varnava-Marouchou, D., Mihai, S., \& Konis, E. (2014). Teaching for Creativity in Universities. Journal of Education and Human Development, 3(4). https://doi.org/10.15640/jehd.v3n4a13

Piawa, C. Y. (2010). Building a test to assess creative and critical thinking simultaneously. Procedia - Social and Behavioral Sciences, 2(2), 551-559. https://doi.org/10.1016/j.sbspro.2010.03.062

Tofade, T., Elsner, J., \& Haines, S. T. (2013). Best practice strategies for effective use of questions as a teaching tool. American Journal of Pharmaceutical Education, 77(7). https://doi.org/10.5688/ajpe777155 
Valenti, S., Neri, F., \& Cucchiarelli, A. (2003). An Overview of Current Research on Automated Essay Grading. Journal of Information Technology Education: Research, 2, 319-330. https://doi.org/10.28945/331 